\title{
Sensitivity of seedlings from different oak species to waterlogging: effects on root growth and mineral nutrition
}

\author{
M Colin-Belgrand 1, E Dreyer 2*, P Biron 1 \\ 1 Laboratoire d'Étude des Sols et de la Nutrition, INRA Nancy, Champenoux, 54280 Seichamps; \\ 2 Laboratoire de Bioclimatologie et d'Ecophysiologie Forestière, INRA Nancy, \\ Champenoux, 54280 Seichamps, France
}

(Received 16 August 1990; accepted 30 November 1990)

Summary - The tolerance of oak seedlings from 3 species (Quercus robur, $Q$ rubra, $Q$ palustris) to a 7-wk period of waterlogging was tested under greenhouse conditions. The seedlings had completed their height growth when treatments were applied. A permanent water table was maintained at 6 $\mathrm{cm}$ below the soil surface. Shoot growth, root growth and mineral content of xylem sap (P, K, Ca, $\mathrm{Mg}$ ) and leaf tissues $(\mathrm{N}, \mathrm{P}, \mathrm{K}, \mathrm{Ca}, \mathrm{Mg}, \mathrm{S}, \mathrm{Mn}$ ) were monitored weekly. Waterlogging had strong consequences on root development; flooded roots decayed, while hypertrophied lenticels and subsequently adventitious roots appeared on the taproot. Although the mineral nutrient content in xylem sap displayed significant differences between species, no effect of waterlogging could be detected. But the combination of constant concentration and reduced transpiration in waterlogged seedlings probably resulted in a reduced nutrient flux to the leaves. Leaf nutrient contents decreased markedly, in particular for total $\mathrm{N}$, and to a lesser extent for $\mathrm{S}$ and $\mathrm{K}$; but in all cases they remained well above deficiency levels. No phytotoxic accumulation of Mn could be detected. Important interspecific differences appeared. The development of root adaptations was much greater for $Q$ robur than for both $Q$ palustris and $Q$ rubra, probably indicating a higher tolerance to flooding in the former species. Surprisingly, $N$ and $S$ concentrations decreased more in $Q$ robur than in both other species, but this could be due to the fact that only $Q$ robur continued leaf growth, leading to a dilution of $N$ in leaf tissues.

hypoxia / Quercus palustris / Quercus rubra / Quercus robur / xylem sap

Résumé - Sensibilité à l'ennoyage de semis de plusieurs espèces de chêne : effets sur la crolssance racinaire et le statut nutritlonnel. La tolérance à l'hypoxie racinaire a été testée sur des semis de 3 espéces de chênes (Quercus robur, Q rubra, $Q$ palustris) au cours d'une période d'ennoyage contrôlé de 7 semaines. La nappe d'eau permanente était maintenue à $6 \mathrm{~cm}$ de la surface du sol, et ce traitement a été appliqué à la fin de la période de croissance active en hauteur. La croissance aérienne, racinaire, et les teneurs en éléments minéraux de la sève brute $(P, K, \mathrm{Ca}, \mathrm{Mg})$ et des tissus foliaires ( $N, P, K, C a, M g, S, M n)$ ont été mesurées hebdomadairement. L'ennoyage a provoqué de fortes perturbations de la croissance racinaire; les racines ennoyées ont rapidement dépéri, alors que des lenticelles hypertrophiées, puis des racines adventives sont progressivement

\footnotetext{
* Correspondence and reprints
} 
apparues au collet du pivot racinaire. Les teneurs en éléments minéraux de la sève ont présenté des différences interspécifiques significatives, mais aucune modification induite par la contrainte n'a pu être détectéé. Étant donnée la réduction observée de la transpiration, cette constance des concentrations s'est cependant probablement traduite par une forte réduction du flux total d'éléments minéraux vers les feuilles. Les teneurs foliaires en éléments minéraux ont sensiblement diminué au cours do l'ennoyage, en particulier en ce qui concerne $N$, et dans une moindre mesure $S$; mais dans tous les cas, les concentrations foliaires sont restées largement au-dessus des seuils de carence décrits pour les chênes. L'ennoyage ne s'est pas traduit par une accumulation toxique de Mn. D'importantes différences interspécifiques dans les réactions à la contrainte sont apparues. La néoformation racinaire a été beaucoup plus importante chez $Q$ robur que chez $Q$ palustris et $Q$ rubra, ce qui semble indiquer une meilleure tolérance à l'ennoyage chez la première espèce. Les concentrations foliaires de $N$ et $S$ ont plus fortement diminué chez $\mathrm{Q}$ robur que dans les 2 autres espèces, mais cette différence est probablement due au maintien d'une certaine croissance chez $Q$ robur, entrainant une dilution de l'azote initialement présent et non renouvelé du fait de l'ennoyage.

\section{hypoxie racinaire / Quercus palustris / Quercus robur / Quercus rubra / sève sylémique}

\section{INTRODUCTION}

Forest trees display a broad spectrum of tolerances to waterlogging. Their degree of tolerance is often estimated from either duration of survival or measured growth and productivity in forest stands or young plantations submitted to root hypoxia due to flooding under natural conditions. Survival time may vary from a few wk for the most sensitive species, to several (2-3) yr for the most tolerant ones (Kozlowski, 1982). Large differences in tolerance sometimes appear in closely related species, and the underlying physiological mechanisms are seldom clearly analysed.

Oak species vary greatly in their sensitivity to waterlogging. Some oak species are common in bottomlands and floodplains and seem very flood-tolerant. For instance, survival under inundation was 2-3 yr for Quercus nigra, $Q$ nuttali and $Q$ phellis (Hall et al, 1946; in Kozlowski, 1982). $Q$ palustris did not show altered water relations after 2 yr of continuous flooding in the central Mississipi valley, although it displayed premature leaf yellowing and abscission (Black, 1984). $Q$ robur is thought to tolerate up to $97 \mathrm{~d}$ of flooding every year (Dister, 1983). $Q$ robur and $Q$ petraea exhibit different behaviours when planted in temporarily waterlogged soils in Northeastern France. The former species seems to present a better tolerance to soil hypoxia at the seedling stage, as shown by growth experiments with different depths of water tables (Lévy et al; 1986). But the latter displays a better productivity on temporary flooded soils in forest stands and shows much larger increases of growth following mechanical soil drainage (Becker and Lévy, 1986). At the seedling stage, a rating of decreasing flood tolerance showed that $Q$ robur behaved better than $Q$ petraea, and $Q$ rubra had the poorest growth (Belgrand, 1983).

Differences in waterlogging tolerance between $Q$ rubra, $Q$ petraea and $Q$ robur appeared strongly correlated with a differentiated ability to develop root adaptations (Belgrand, 1983). In fact, the most frequently reported reaction of trees to soil hypoxia is the induction of morphological and anatomical changes in the root systems of flood-tolerant species (Justin and Armstrong, 1987). Formation of hypertrophied lenticels followed by the differentiation of adventitious and flood-adapted roots has been commonly described for a broad range of species (Coutts and Arm- 
strong, 1976; Coutts, 1982; Harrington, 1987; McKevlin et al, 1987).

Flooding induces important perturbations in mineral nutrient assimilation. Leaf $\mathbf{N}$ content of Picea abies was strongly reduced by flooding (Lévy, 1981). For most elements (N, K, Fe, Mn and to a lesser extent $\mathrm{Mg}$ and $\mathrm{Ca}$ ) leaf content was reduced in different Pinus species after $30 \mathrm{~d}$ of root hypoxia in nutrient solutions (Topa and McLeod, 1986). But these effects were mainly observed with trees still growing during the waterlogging period. No information on mineral nutrients circulating in the xylem sap of waterlogged seedlings is currently available.

In this study, we compared 3 species known to differ in their waterlogging tolerance ( $Q$ robur, $Q$ rubra and $Q$ palustris) and tested their ability to produce adventitious roots in response to a 7-wk flooding. We tried to assess the consequences of these differences on the transport of mineral nutrients to shoots, and on the leaf mineral content. In a forthcoming paper (Dreyer et al, 1991) the consequences of the observed perturbation in root growth on shoot physiology will be assessed.

\section{MATERIALS AND METHODS}

\section{Plant material}

Acorns were collected during autumn 1987, under individuals of $Q$ robur $L$ (Amance Forest, near Nancy, France), $Q$ rubra $L$ (Fénétrange Forest, Moselle, France) and $Q$ palustris Muenchh (Pujo Forest, Tarbes, Hautes Pyrénées, France). Acorns were stored at $-1{ }^{\circ} \mathrm{C}$ and sown during the following February in special individual $5-\mathrm{I}, 25-\mathrm{cm}$ deep pots, containing a 50 / $50 \mathrm{v} / \mathrm{v}$ mixture of peat/sandy loam. The main features of this substrate are shown in table I. An external transparent vertical tubing was connected to the bottom of these pots, allowing a precise control of water table level. Seedlings were grown in a glasshouse near Nancy; day temperatures were maintained between 20$30^{\circ} \mathrm{C}$, with a night temperature of $16{ }^{\circ} \mathrm{C}$ maintained through heating, and humidity $\approx 60 \%$. No additional light was supplied. Height growth was monitored weekly from germination on.

\section{Waterlogging}

Plants were flooded with tap water on June 15th. The upper level of the water table was adjusted daily to $6 \mathrm{~cm}$ below the soil surface, and maintained for 7 wk. Pots were then drained and seedlings allowed to grow for 2 more wk. Sixty plants were used for each species, with 30 randomly selected as controls and 30 treated. The experimental design consisted of 3 blocks ( 1 per species), in which treatments were randomly distributed. Destructive measurements (biomass, water status, nutrient content and xylem sap composition) were made weekly on 2 randomly selected waterlogged and 2 control plants. Roots were rinsed with tap water. The structure of the root system was observed; in particular, the presence of lenticels and the degree of root senescence were assessed visually. Root systems were divided thereafter into old roots, white tips and neoformed roots, and were oven-dried $\left(65^{\circ} \mathrm{C}\right.$ for $24 \mathrm{~h}$ ). Leaves and stems were used for mineral content analysis.

\section{Water status and xylem sap extraction}

Shoots of selected plants $(2$ control and 2 treated saplings per species) were cut off once weekly after being submitted to at least $12 \mathrm{~h}$ darkness, and predawn leaf water potential $\left(\psi_{\mathrm{wb}}\right)$ was measured with a pressure chamber. After attaining the balancing pressure, the bark was removed from the cut end, the pressure was slowly increased to $2.5 \mathrm{MPa}$, and maintained for $5 \mathrm{~min}$. Extruding sap was collected with a micropipette and frozen immediately in liquid nitrogen before being stored at $-18^{\circ} \mathrm{C}$. Roots were rinsed with tap water and xylem sap was extracted by the same technique as for the shoots. 
Table I. Main substrate properties and amounts of fertiliser added to the 5-1 pots in which the seedlings were grown. Fertilisation was added once at the beginning of the growth period.

\begin{tabular}{lc} 
Organic matter (\%) & 15.14 \\
Total nitrogen (Kjeldahl) (\%) & 0.62 \\
$\mathrm{C} / \mathrm{N}$ & 14.2 \\
pH & 5.12 \\
Phosphorus (\%) & 0.31 \\
Exchangeable $\mathrm{Ca}(\mathrm{meq} / 100 \mathrm{~g})$ & 3.5 \\
Exchangeable $\mathrm{Mg}(\mathrm{meq} / 100 \mathrm{~g})$ & 0.46 \\
Exchangeable $\mathrm{K}(\mathrm{meq} / 100 \mathrm{~g})$ & 0.26 \\
Exchangeable $\mathrm{Na}(\mathrm{meq} / 100 \mathrm{~g})$ & 0.068 \\
Added fertiliser & \\
$\mathrm{K}$ (meq $\left.\mathrm{KH}_{2} \mathrm{PO}_{4} / \mathrm{pot}\right)$ & 38.4 \\
$\mathrm{P}$ (meq $\left.\mathrm{KH}_{2} \mathrm{PO}_{4} / \mathrm{pot}\right)$ & 38.4 \\
$\mathrm{~N}$ (meq NH $\left.\mathrm{NO}_{3} / \mathrm{pot}\right)$ & 88.6 \\
$\mathrm{Mg}$ (meq $\left.\mathrm{MgSO}_{4} 7 \mathrm{H}_{2} \mathrm{O} / \mathrm{pot}\right)$ & 20.6 \\
\hline
\end{tabular}

\section{Mineral analyses}

Concentrations of $\mathrm{P}, \mathrm{K}, \mathrm{Mg}$ and $\mathrm{Ca}$ in the xylem sap were measured directly with an inductively coupled plasma spectrometer (ICP, Jobin Yvon). Nutrient concentrations were measured together on the leaves of 2 seedlings, and the results were therefore mean concentrations of both seedlings. Total leaf nitrogen was determined by Kjeldahl mineralization and a colorimetric procedure (Technicon Autoanalyser), while leaf $\mathrm{P}, \mathrm{Ca}, \mathrm{Mg}, \mathrm{K}, \mathrm{S}$ and $\mathrm{Mn}$ concentrations were determined after wet mineralization $\left(\mathrm{HClO}_{4}+\mathrm{H}_{2} \mathrm{O}_{2}\right)$ and ICP quantitation.

\section{Statistical analysis}

Results were analysed using an ANOVA and testing for differences between collection dates, species and treatments. As soon as no significant change could be detected over a longer period of time, data were gathered for the main waterlogging period (ie, from wk 1-7) and compared directly with corresponding controls using a Student $t$-test; $n=14$ for root and shoot xylem sap, and $n=7$ for leaf mineral content.

\section{RESULTS}

\section{Effects of flooding on shoot and root growth}

Flooding was imposed after complete shoot growth cessation in $Q$ rubra and $Q$ palustris as shown by growth dynamics (fig 1). Two growth flushes had been completed on $Q$ rubra and $Q$ palustris; while a 3rd flush was beginning on $Q$ robur. In this latter case, flooding slightly reduced height growth, while in the former 2 species, it

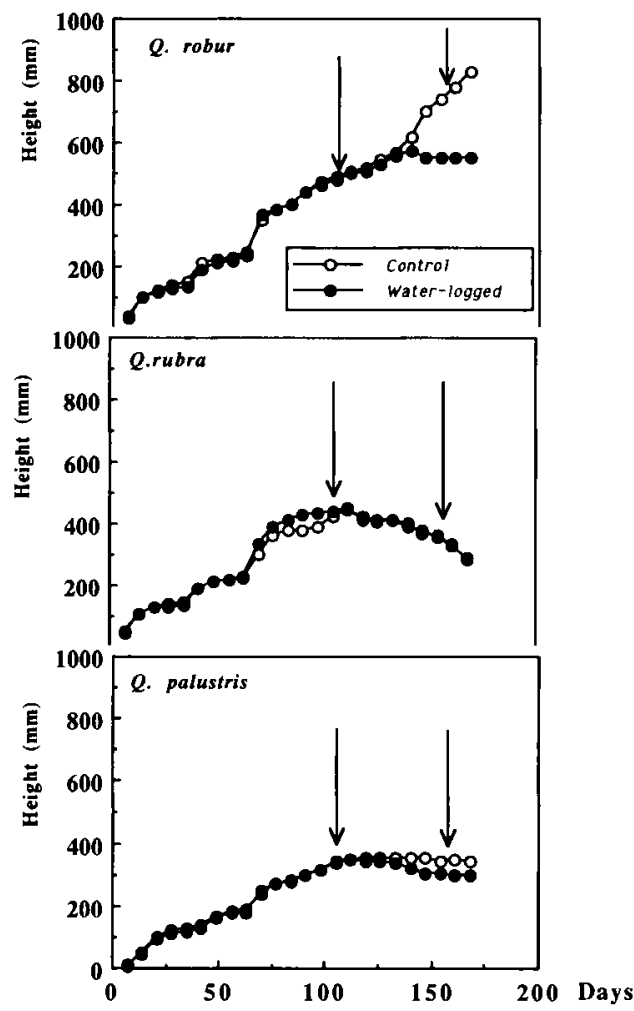

Fig 1. Mean height growth of seedlings from 3 oak species submitted or not to waterlogging. Arrows indicate beginning and end of waterlogging. $n=30$ before waterlogging and decreased by 2 plants every week afterwards. 
had no effect no shoot growth; an apparent decrease in height for $Q$ rubra was only due to recurrent sampling and consequent reduction of plant number. No resumption of growth occurred after drainage. Leaf characteristics were very different between species but were not dramatically affected by waterlogging (table II). $Q$ rubra had the largest leaf area per plant despite limited height, and the largest leaf specific weight, while $Q$ robur showed only $2 / 3$ of this area, and $Q$ palustris had lower area and specific leaf weights. Flooding had no significant effect on these parameters; specific leaf weight increased slightly but this increase was only significant for $Q$ robur. No leaf necrosis was detected during the entire period.

Root growth dynamics were much more affected by flooding. Some morphological features were common to all species: flooding induced a rapid decay of preexisting roots, with senescence and disappearance of white tips, and necrosis of tap root and flooded lateral roots.

Hypertrophied lenticels appeared by the end of the 3rd week at the root collar and on non flooded roots and developed markedly. Finally, adventitious roots were formed from the 4 th week on, in the soil

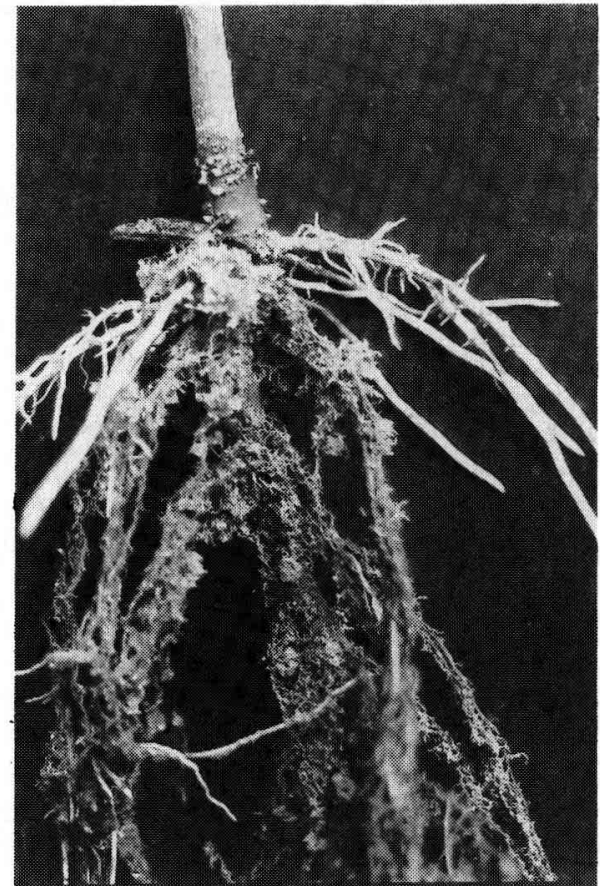

Fig 2. Appearance oi new roots on $Q$ robur seedlings by the end of the 4th week of waterlogging. New roots were mainly growing above the water table. Note the presence of hypertrophied lenticels at the root collar, and the senescing old root system. New roots increased in diameter, were non ramified and non suberized, and grew only above the water table.

Table II. Total leaf area per seedling (LA) and specific leaf weight (SLW) for control and waterlogged plants. As no clear evolution in any of these parameters could be observed from wk $1-7$, all data have been considered as individual repetitions. $n=14$.

\begin{tabular}{|c|c|c|c|c|c|c|}
\hline & \multicolumn{2}{|c|}{$\underset{\left(d m^{2}\right)}{L A}$} & \multirow[t]{2}{*}{$\begin{array}{l}\text { Treatment } \\
\text { signif }\end{array}$} & \multicolumn{2}{|c|}{$\underset{\left(g d m^{-2}\right)}{L S W}$} & \multirow[t]{2}{*}{$\begin{array}{c}\text { Treatment } \\
\text { signif }\end{array}$} \\
\hline & Control & Flooded & & Control & Flooded & \\
\hline $\begin{array}{l}Q \text { robur } \\
Q \text { rubra } \\
Q \text { palustris } \\
\text { Species }\end{array}$ & $\begin{array}{r}7.09 \\
12.40 \\
4.97 \\
* \pm \pm\end{array}$ & $\begin{array}{r}7.63 \\
11.09 \\
5.20 \\
* \star \star\end{array}$ & $\begin{array}{l}- \\
\overline{-}\end{array}$ & $\begin{array}{l}0.534 \\
0.625 \\
0.567 \\
\star \star\end{array}$ & $\begin{array}{l}0.601 \\
0.644 \\
0.598\end{array}$ & $\begin{array}{l}* * * \\
- \\
-\end{array}$ \\
\hline
\end{tabular}

Significance of differences between species or treatments are assessed with following symbols: - (no significance); * $P<0.05 ;{ }^{* *} P<0.01 ; * * * P 0.001$. 
above the water table. These new roots were poorly ramified, had a larger diameter, and were not suberized even after 4 wk (fig 4).

These reactions occurred in all species, but with very different intensities. $Q$ robur seedlings developed abundant hypertrophied lenticels by the end of the 3rd wk, and numerous adventitious roots appeared after 4 wk of waterlogging. $Q$ rubra seedlings showed a remarkable hypertrophy of stem and lenticels but only very few adventitious roots, which appeared only after 6 wk of flooding. $Q$ palustris displayed only few adventitious roots, and almost no lenticels or stem hypertrophy.

As shown in fig $3 \mathrm{a}$, total root biomass (including senescing roots) was slightly decreased in flooded $Q$ rubra and $Q$ palustris after 4 wk of waterlogging but increased in $Q$ robur as compared to the control. A strong decrease in the biomass of white tips, eg growing root apices, appeared at the same time (fig $3 b$ ) in response to flooding in all species. The total weight of adventitious roots was very variable: $Q$ robur developed the largest amount, while $Q$ rubra and $Q$ palustris formed only very few such roots. In $Q$ robur, they achieved a substantial biomass (fig $3 b$ ).
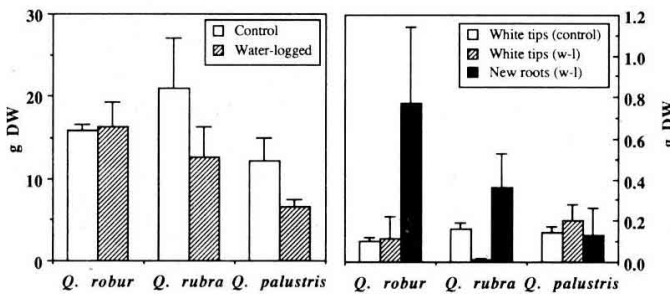

Fig 3. Comparison between waterlogged and control plant root systems. Data were obtained between wk 5-8. (a) Total root biomass, including senescent roots on flooded plants; (b) biomass of white tips (control and flooded) and adventitious roots (only on waterlogged plants). Each value is the mean of 8 plants. Bars represent the standard error of the mean.

\section{Effects of flooding on nutrient transport in the xylem sap and on shoot nutrient status}

Table III shows the measured concentrations of mineral nutrients in the xylem sap extracted from roots and shoots. As no significant change could be detected in control or in flooded plants after wk 1, we compared all the data collected till the end of the waterlogging period directly. As a general rule, nutrient concentrations were about twice as high in the sap extracted from roots than in the sap from shoots. Significant differences related to species were found for all the tested elements, with the exception of $\mathrm{Ca}$. $Q$ robur showed the highest concentrations of $\mathrm{Mg}$ and $\mathrm{K}$, while $Q$ rubra had the highest concentrations of $P$. Only seldom were the effects of flooding statistically significant. Significant reductions only appeared for $\mathrm{K}$ and $\mathrm{Ca}$ in $Q \mathrm{pa}$ lustris and in $Q$ rubra. Large variations between individual plants did not allow closer comparisons.

Leaf nutrient contents showed large differences between species. Total $\mathbf{N}$ was significantly higher in $Q$ robur, while $\mathrm{Ca}$ was more concentrated in $Q$ rubra (table IV). The total mass of nutrients present in the leaves was much higher in $Q$ rubra due to a larger leaf area than in $Q$ robur and $Q$ palustris (table IV). Flooding induced a highly significant reduction in total leaf $\mathrm{N}$, and significant reductions in $\mathrm{S}$ contents. The reduction in leaf nitrogen appeared very rapidly in $Q$ robur, for which it was highly significant; it was less marked and slower but still significant in $Q$ rubra and $Q$ palustris (fig 4). Reductions in $S$ and $K$ also appeared in $Q$ robur, and were non significant for both the other species. No phytotoxic increase in $\mathrm{Mn}$ could be observed. 
Table III. Effects of flooding on the nutrient concentration in xylem sap extracted either from roots or from shoots of seedlings from 3 oak species. Data were collected weekly during a 7-wk flooding period on 2 seedlings per species. In the absence of significant change after wk 1, all results were tested together using a factorial ANOVA. $n=14$.

\begin{tabular}{|c|c|c|c|c|c|c|c|c|c|}
\hline \multirow[b]{2}{*}{ Species } & \multirow[b]{2}{*}{$m o l m^{3}$} & \multicolumn{4}{|c|}{ Root xylem sap } & \multicolumn{4}{|c|}{ Shoot xylem sap } \\
\hline & & $P$ & $K$ & $\mathrm{Ca}$ & $M g$ & $P$ & $\kappa$ & $\mathrm{Ca}$ & $M g$ \\
\hline \multirow[t]{2}{*}{ Q robur } & $\begin{array}{l}\text { Control } \\
\text { Waterlogged }\end{array}$ & $\begin{array}{l}2.52 \\
2.22\end{array}$ & $\begin{array}{l}8.74 \\
7.69\end{array}$ & $\begin{array}{l}2.44 \\
2.38\end{array}$ & $\begin{array}{l}2.17 \\
2.13\end{array}$ & $\begin{array}{l}1.31 \\
1.37\end{array}$ & $\begin{array}{l}5.97 \\
5.22\end{array}$ & $\begin{array}{l}1.13 \\
1.56\end{array}$ & $\begin{array}{l}1.16 \\
1.32\end{array}$ \\
\hline & Signif & - & - & - & - & - & - & - & - \\
\hline \multirow[t]{2}{*}{ Q rubra } & $\begin{array}{l}\text { Control } \\
\text { Waterlogged }\end{array}$ & $\begin{array}{l}3.63 \\
4.73\end{array}$ & $\begin{array}{l}6.13 \\
5.45\end{array}$ & $\begin{array}{l}3.11 \\
2.39\end{array}$ & $\begin{array}{l}1.43 \\
1.77\end{array}$ & $\begin{array}{l}2.21 \\
2.37\end{array}$ & $\begin{array}{l}4.06 \\
2.25\end{array}$ & $\begin{array}{l}1.07 \\
0.97\end{array}$ & $\begin{array}{l}0.89 \\
0.82\end{array}$ \\
\hline & Signif & - & - & - & - & - & $* *$ & - & - \\
\hline Q palustris & $\begin{array}{l}\text { Control } \\
\text { Waterlogged } \\
\text { Signif }\end{array}$ & $\begin{array}{l}3.33 \\
2.35 \\
-\end{array}$ & $\begin{array}{l}7.57 \\
4.63 \\
\star *\end{array}$ & $\begin{array}{l}3.43 \\
1.51 \\
* * *\end{array}$ & $\begin{array}{c}1.33 \\
1.52 \\
-\end{array}$ & $\begin{array}{l}1.88 \\
1.73 \\
-\end{array}$ & $\begin{array}{l}2.96 \\
2.11\end{array}$ & $\begin{array}{c}0.79 \\
0.96 \\
-\end{array}$ & $\begin{array}{c}0.62 \\
0.75 \\
-\end{array}$ \\
\hline Species & & $* * *$ & $\star \star$ & - & $* * *$ & $* * *$ & $\star \star \star$ & - & $* * *$ \\
\hline
\end{tabular}

Significance of differences is indicated as follows: - (no significance); $P<0.05 ;{ }^{* *} P<0.01 ;{ }^{\cdots *} P<0.001$. The last line shows degree of significance of differences between species.

\section{DISCUSSION}

\section{Shoot growth}

The experiment was designed to assess the waterlogging effects on well developed seedlings which had already completed their annual growth. Effects on shoot growth were therefore only detected in $Q$ robur which was the only species still displaying growth. The limited increases in specific leaf weight and the lack of necrosis showed that waterlogging had no deleterious effects on the leaves. However, this result cannot be generalised, as growing leaves probably would have reacted differently.

\section{Root adaptations}

Root reactions were very strong in all 3 species. Decay of the flooded fraction of the root systems occurred during the first few weeks, with apparently the same intensity for all seedlings. The appearance of hypertrophied lenticels and adventitious roots in the soil layers above the water table was also noted in all seedlings, although with different intensities. These root reactions are a common feature of waterlogging effects on tree seedlings; they have been observed on a wide range of species including Quercus macrocarpa (Tang and Kozlowski, 1982), Fraxinus pennsylvanica (Gomes and Kozlowski, 1980), Alnus rubra and Populus trichocar- 
Table IV. Nutrient contents in leaves expressed on a dry weight ( $\mathrm{g} \mathrm{kg}^{-1} \mathrm{DW}$ ) or a seedling $\left(\mathrm{mg}\right.$ plant $\left.{ }^{-1}\right)$ basis. A. Comparison of species (including both treatments); $B$. Effects of waterlogging treatments for each species. Two seedlings per treatment were dried and analysed together weekly for 7 wk. In the absence of any significant change after wk 1 , all results were tested together using a factorial ANOVA. $n=7$.

\begin{tabular}{|c|c|c|c|c|c|c|c|c|}
\hline \multicolumn{2}{|l|}{ A. Species } & $N$ & $P$ & $K$ & $\mathrm{Ca}$ & $M g$ & $s$ & $M n$ \\
\hline \multicolumn{2}{|c|}{$\begin{array}{l}\text { Q robur }\left(\mathrm{g} \mathrm{kg}^{-1}\right) \\
Q \text { rubra }\left(\mathrm{g} \mathrm{kg}^{-1}\right) \\
Q \text { palustris }\left(\mathrm{g} \mathrm{kg}^{-1}\right) \\
\text { Signif }\end{array}$} & $\begin{array}{l}29.7 \\
25.3 \\
24.1 \\
2 * * *\end{array}$ & $\begin{array}{c}1.55 \\
1.29 \\
1.63 \\
-\end{array}$ & $\begin{array}{l}7.51 \\
7.77 \\
6.34\end{array}$ & $\begin{array}{c}9.90 \\
14.40 \\
8.20 \\
\end{array}$ & $\begin{array}{c}1.94 \\
1.76 \\
1.63 \\
-\end{array}$ & $\begin{array}{l}2.31 \\
2.06 \\
1.94 \\
-\end{array}$ & $\begin{array}{c}5.09 \\
6.32 \\
6.49 \\
-\end{array}$ \\
\hline \multicolumn{2}{|c|}{$\begin{array}{l}Q \text { robur (mg.plant }{ }^{-1} \text { ) } \\
Q \text { rubra (mg.plant } \\
\text { Q palustris (mg.plant } \\
\text { Q })\end{array}$} & $\begin{array}{r}124 \\
188 \\
71\end{array}$ & $\begin{array}{l}6.46 \\
9.60 \\
4.82\end{array}$ & $\begin{array}{l}31.3 \\
57.8 \\
18.8\end{array}$ & $\begin{array}{l}41.2 \\
107 \\
24.3\end{array}$ & $\begin{array}{l}8.09 \\
13.1 \\
4.82\end{array}$ & $\begin{array}{l}9.63 \\
15.3 \\
5.74\end{array}$ & $\begin{array}{l}21.1 \\
47.0 \\
19.2\end{array}$ \\
\hline \multicolumn{2}{|c|}{ B. Treatment } & $N$ & $P$ & $K$ & $\mathrm{Ca}$ & $M g$ & $s$ & $M n$ \\
\hline Qrobur & $\begin{array}{l}\text { Control } \\
\text { Waterlogged } \\
\text { Signif }\end{array}$ & $\begin{array}{l}33.4 \\
26.6 \\
* * *\end{array}$ & $\begin{array}{c}1.70 \\
1.28 \\
-\end{array}$ & $\begin{array}{l}8.23 \\
6.60 \\
-\end{array}$ & $\begin{array}{l}9.47 \\
8.32 \\
-\end{array}$ & $\begin{array}{l}1.80 \\
1.92 \\
-\end{array}$ & $\begin{array}{l}2.53 \\
2.05\end{array}$ & $\begin{array}{c}5.02 \\
4.03 \\
-\end{array}$ \\
\hline Q rubra & $\begin{array}{l}\text { Control } \\
\text { Waterlogged } \\
\text { Signif }\end{array}$ & $\begin{array}{l}23.3 \\
24.7 \\
.\end{array}$ & $\begin{array}{c}1.37 \\
1.23 \\
-\end{array}$ & $\begin{array}{l}8.16 \\
8.84 \\
-\end{array}$ & $\begin{array}{c}14.3 \\
14.3 \\
-\end{array}$ & $\begin{array}{l}1.69 \\
1.76 \\
-\end{array}$ & $\begin{array}{l}2.04 \\
2.14 \\
-\end{array}$ & $\begin{array}{r}7.40 \\
5.20 \\
-\end{array}$ \\
\hline Q palustris & $\begin{array}{l}\text { Control } \\
\text { Waterlogged } \\
\text { Signif }\end{array}$ & $\begin{array}{l}26.9 \\
21.9 \\
* \star\end{array}$ & $\begin{array}{c}1.57 \\
2.06 \\
-\end{array}$ & $\begin{array}{l}7.07 \\
6.34 \\
-\end{array}$ & $\begin{array}{c}9.12 \\
8.80 \\
-\end{array}$ & $\begin{array}{l}1.65 \\
1.84 \\
-\end{array}$ & $\begin{array}{l}2.13 \\
1.88 \\
-\end{array}$ & $\begin{array}{l}5.97 \\
6.40 \\
-\end{array}$ \\
\hline
\end{tabular}

Significance of differences is indicated as follows: - (no significance); ${ }^{*} P<0.05 ;{ }^{* *} P<0.01 ;{ }^{* * *} P<0.001$.

pa (Harrington, 1987), Actinidia chinensis (Savé and Serrano, 1986), Gmelina arborea (Osonubi and Osundina, 1987), Cryptomeria japonica (Yamamoto and Kozlowski, 1987), Picea sitchensis (Coutts, 1981), Pinus contorta (Coutts and Philipson, 1978) and many others.

Flood-induced roots are white, thick, more succulent and poorly ramified, and lack root hairs; they display both larger cells and aerenchyma (Keeley, 1979; Angeles et al, 1986; Justin and Armstrong, 1987). These modifications are supposed to improve oxygen diffusion through hypertrophied lenticels and gas transport to non aerated roots (Hook et al, 1971; Keeley, 1979; Drew, 1983). They may also be associated with resistance to iron or manganese toxicity (Green and Etherington, 1977).

\section{Mineral nutrition}

The reliability of our xylem sap extraction technique with relatively high pressure (2.5 


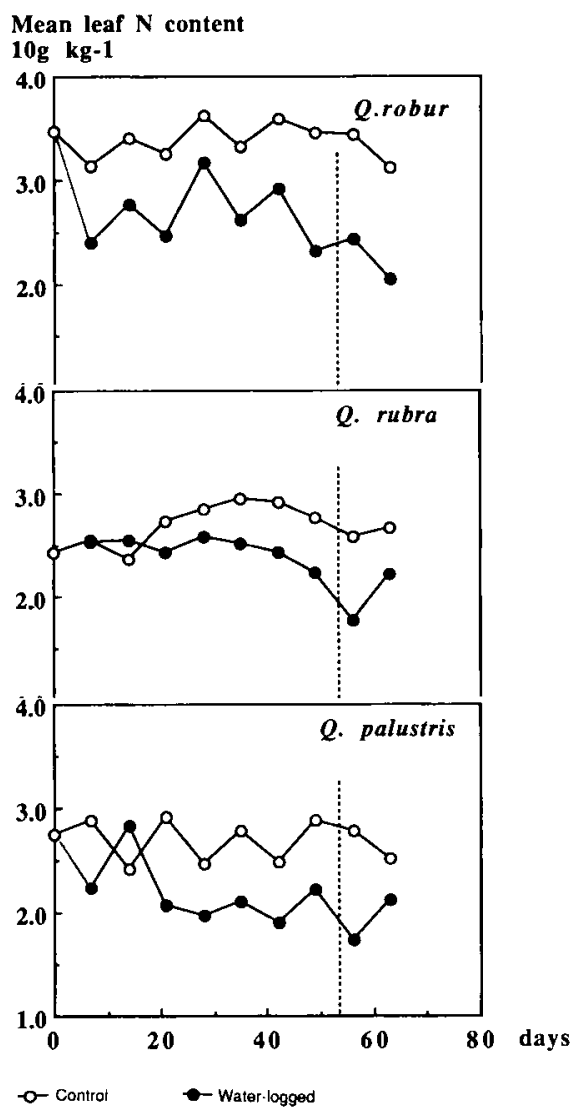

Fig 4. Evolution of total leaf nitrogen content during waterlogging in the 3 oak species. Each value has been obtained from 2 seedlings, dried and analysed together.

MPa) may be questioned. The fact that concentrations were about twice as high in sap extracted from roots than from shoots may be partly explained by the differences in ion mobilisation in pressurized roots vs shoots. Concentrations of $\mathrm{K}, \mathrm{Mg}$ and $\mathrm{Ca}$ measured by Scuiller (1990) in seedlings of different Quercus species growing on the same substrate were very similar to ours. Despite a large interindividual variability, significant differences appeared between species independently from water- logging, particularly for $\mathrm{P}, \mathrm{Mg}$ and $\mathrm{K}$. Could these differences be related to different growth habits ? $Q$ robur, displaying the highest $K$ and $\mathrm{Mg}$, had the greatest height growth, while $Q$ rubra, with higher $P$, built up the largest leaf area. But concentrations are not necessarily correlated with the total nutrient fluxes from roots to shoots. In fact, transpiration was lower in $Q$ rubra despite its larger leaves (Dreyer et al, 1991) and total nutrient fluxes therefore lower. $Q$ palustris had the lowest concentrations and transpiration rates among the 3 species, and therefore probably the lowest nutrient transport to the leaves.

Waterlogging had only very limited effects on the xylem sap concentrations; significant reductions only appeared for $K$. We do not know of any other attempt to analyse flooding effects on xylem sap contents. Effects of water stress on xylem sap composition have sometimes been assessed; Scuiller (1990) observed only limited increases in osmotic potential and ion concentrations with decreasing predawn leaf water potential. It may be concluded that the stability of xylem sap concentrations, associated with a reduced transpiration flux (Dreyer et al, 1991), probably resulted in a reduction of the total flux of mineral nutrients to shoots in waterlogged seedlings.

Leaf mineral contents of our seedlings were for all species and treatments well above the deficiency levels for oaks (Bonneau, 1986). Large interspecies differences were observed for $N$ and $\mathrm{Ca}$. Despite the fact that $Q$ rubra is a well known calcifuge species, it concentrated $\approx 2 / 3$ more $\mathrm{Ca}$ in its leaves than the other 2 species. But $Q$ robur displayed much higher $N$ contents, which may be correlated with the higher rates of photosynthesis observed in this species (Dreyer et al, 1991). Q rubra mobilized the largest total amount of nutrients due to its high leaf area. The effects 
of waterlogging on leaf nutrient contents were limited and showed a great variability between species and measured elements. Observed decreases in total N, which appeared in $Q$ robur seedlings and to a lesser extent in the other species, were in accordance with earlier observations by Lévy (1981) with Picea abies, or Meyer et al (1986) with Gossypium hirsutum. In fact, decreases in $\mathbf{N}$ contents are often the earliest response to flooding (Drew and Sisworo, 1979; Meyer et al, 1986; Harrington, 1987). These decreases may either be due to nitrate reduction and accelerated denitrification (Lévy, 1981), or to the inability of the roots to take up enough $\mathrm{N}$ even before the onset of strong denitrification (Drew and Sisworo, 1979; Meyer et al, 1987). Decreases in other elements in $Q$ robur were not statistically significant. In both the other species, apart from decreases in $\mathrm{N}$, no difference could be detected. In this respect, our results differ from earlier reports, which showed significant decreases in almost all the tested elements (N, P, K in 3 different Pinus species; Topa and McLeod, 1986; K, Mg in Alnus rubra and Populus trichocarpa; Harrington, 1987). In fact, improving soil fertility often limits the effects of waterlogging on tree growth (De Bell et al, 1984), but in these cases, flooding was imposed on actively growing plants, while our seedlings had almost stopped shoot and leaf growth.

Only $Q$ robur maintained to some extent growth and also displayed the most significant reductions in leaf mineral contents. Further data are needed to clarify mineral budgets of saplings submitted to waterlogging and flooding.

Mn toxicity, which has been associated with waterlogging by some authors (Sonneveld and Voogt, 1975) was not detected here; Mn contents decreased or remained at the same levels as in controls, as was also observed by Topa and McLeod (1986) and Harrington (1987).

\section{Comparison of waterlogging tolerance among species}

The 3 oak species tested are thought to display wide differences in waterlogging tolerance. $Q$ robur is supposed to tolerate root hypoxia (Lévy et al, 1986), $Q$ rubra is well known for its marked intolerance, while $Q$ palustris is supposed to be more tolerant (Abbott and Dawson, 1983). The intensity of the root reactions observed was in agreement with these observations for $Q$ robur and $Q$ rubra and confirmed earlier findings (Belgrand, 1983). The weak reactions of $Q$ palustris roots were surprising and may have been caused by our particular growth conditions. Root reactions of actively growing seedlings may be very different from those observed here.

Differences in root reaction were not followed by strong differences in mineral nutrition. The greatest reductions appeared in $Q$ robur, which showed the largest root adaptations. This could be explained by a dilution of elements, particularly $\mathrm{N}$, in the still growing tissues of $Q$ robur associated with a decrease in absorption. In both the other species, the cessation of growth, which was not related to waterlogging, allowed a relative stability of nutrient contents. In fact, the mineral richness of the culture medium which resulted in mean leaf contents largely above deficiency levels and even above optimal levels (Bonneau, 1986) probably explained this stability.

The most important difference in waterlogging tolerance that we observed was related to the ability of $Q$ robur to develop root adaptations in flooded plants. It is still difficult to develop an analysis of flooding tolerance between species in the absence of a general model of hypoxic stress effects at the whole sapling level. There is still need for further research to improve our knowledge in this area. 


\section{ACKNOWLEDGMENTS}

The authors wish to thank JM Gioria for growing the seedlings, C Bréchet for help in mineral analysis and 2 anonymous reviewers for helpful criticism on the first draft of this manuscript.

\section{REFERENCES}

Abbott WA, Dawson JO (1983) is the tolerance of oak and maple seedlings to applied ethanol related to their ability to tolerate. low soil oxygen levels? For Res Rep, Dept For, Agric Exp Stat IL 83, 1-4

Angeles G, Evert RF, Kozlowski TT (1986) Development of lenticels and adventitious roots in flooded UImus americana seedlings. Can J For Res 16, 585-590

Becker M, Lévy G (1986) Croissance radiale comparée de chênes adultes (Quercus robur $L$ et $Q$ petraea (Matt) Lieb) sur sol hydromorphe acide: effet du drainage. Acta Oecol, Oecol Plant 4, 299-317

Belgrand $M$ (1983) Comportement de jeunes plants feuillus (chêne pédonculé, chêne sessile, hêtre) sur substrat ennoyé. Adaptations racinaires. Application à la mise en valeur forestière sur pseudogley. Thèse Doct Ing, INA Paris-Grignon

Black RA (1984) Water relations of Quercus palustris: field measurements of an experimentally flooded stand. Oecologia 64, 14-20

Bonneau M (1986) Le diagnostic foliaire. Rev For Fr 60, 19-28

Coutts MP (1981) Effects of waterlogging on water relations of actively-growing and dormant Sitka spruce seedlings. Ann Bot 47, 747-753

Coutts MP (1982) The tolerance of tree roots to waterlogging. V. Growth of woody roots of Sitka spruce and Lodgepole pine in waterlogged soil. New Phytol 90, 467-476

Coutts MP, Armstrong W (1976) Role of oxygen transport in the tolerance of trees to water logging. In: Tree Physiology and Yield Improvement (Cannell MGR, Last FT, eds) Academic Press, London, 361-385

Coutts MP, Philipson JJ (1978) Tolerance of tree roots to waterlogging. II. Adaptations of
Sitka spruce and Lodgepole pine to waterlogged soils. New Phytol 80, 71-77

De Bell DS, Hook DD, McKee WH Jr (1984) Growth and physiology of Loblolly pine roots under various water table level and phosphorous treatments. For Sci 30, 705-714

Dister E (1983) Zur Hochwassertoleranz von Auenwaldbăumen an lehmigen Standorten. Verh Gesell Okol 10, 325-336

Drew MC (1983) Plant injury and adaptations to oxygen deficiency in the root environment: a review. Plant Soil 75, 179-199

Drew MC, Sisworo EJ (1979) The development of waterlogging damage in young barley plants in relation to plant nutrient status and changes in soil properties. New Phytol 82, 301-314

Dreyer E, Colin-Belgrand M, Biron P (1991) Photosynthesis and shoot water status of seedlings from four oak species submitted to soil hypoxia. Ann Sci For 22, 00-00

Green MS, Etherington JR (1977) Oxidation of ferrous iron by rice (Oryza sativa $L$ ) roots: a mechanism of waterlogging tolerance? J Exp Bot 28, 678-690

Harrington CA (1987) Responses of Red Alder and Black Cottonwood seedlings to flooding. Physiol Plant 69, 35-48

Hook DD, Brown CL, Kormanik PP (1971) Inductive flood tolerance in Swamp Tupelo (Nyssa sylvatica var biflora (Walt) Sarg). J Exp Bot 22, 78-89

Justin SHFW, Armstrong W (1987) The anatomical characteristics of roots and plant response to soil flooding. New Phytol 106, 465495

Keeley JE (1979) Population differentiation along a flood frequency gradient: physiological adaptations to flooding in Nyssa sylvatica. Ecol Monogr 1979, 89-108

Kozlowski $\Pi$ (1982) Water supply and tree growth. II. Flooding. For Abstr 43, 145-161

Lévy G (1981) La nutrition azotée de l'Epicéa en sol engorgé : étude expérimentale. Ann Sci For 38, 163-178

Lévy G, Becker M, Garreau B (1986) Comportement expérimental de semis de chêne pédonculé, chêne sessile et hêtre en présence d'une nappe d'eau dans le sol. Ann Sci For $43,131-146$ 
McKevlin MR, Hook DD, McKee WH Jr, Wallace SU, Woodruff JR (1987) Loblolly Pine seedling root anatomy and iron accumulation as affected by soil waterlogging. Can J For Res $17,1257-1264$

Meyer WS, Reicosky DC, Barrs HD, Smith RCG (1986) Physiological responses of cotton to a single waterlogging at high and low $\mathrm{N}$-levels. Plant Soil 102, 161-170

Osonubi O, Osundina MA (1987) Comparison of the responses to flooding of seedlings and cuttings of Gmelina. Tree Physio/ 3, 147-156

Savé R, Serrano L (1986) Some physiological and growth responses of kiwi fruit (Actinidia chinensis) to flooding. Physiol Plant 66, 7578

Scuiller I (1990) Exploration de la variabilité des comportements écophysiologiques de semis de chênes blancs européens soumis à la sécheresse. Thèse Doctorat d'Univ, Université de Nancy 1
Gomes S, Kozlowski TT (1980) Growth responses and adaptations of Fraxinus pensylvanica seedlings to flooding. Plant Physiol 66, 267271

Sonneveld C, Voogt SJ (1975) Studies on the manganese uptake of lettuce on steam. sterilized glasshouse soils. Plant Soil 42, 4962

Tang ZC, Kozlowski TT (1982) Some physiological and morphological responses of Quercus macrocarpa seedlings to flooding. Can J For Res 12, 196-202

Topa MA, McLeod KW (1986) Response of Pinus clausa, Pinus serotina and Pinus taeda to anaerobic solution culture. II. Changes in tissue nutrient concentration and net acquisition. Physiol Plant 68, 532-539

Yamamoto F, Kozlowski $\pi$ (1987) Effect of flooding of soil on growth, stem anatomy and ethylene production of Cryptomeria japonica seedlings. Scand J For Res 2, 45-58 